\title{
Asian Carp Behavior in Response to Static Water Gun Firing
}

Megan J. Layhee', Jackson A. Gross ${ }^{1,2}$, Michael J. Parsley', Jason G. Romine', David C. Glover ${ }^{3}$, Cory D. Suski', Tristany L. Wagner ${ }^{1,2}$, Adam J. Sepulveda', and Robert E. Gresswell ${ }^{1}$

\section{Summary}

The potential for invasion of Asian carp into the Great Lakes has ecological and socio-economic implications. If they become established, Asian carp are predicted to alter lake ecosystems and impact commercial and recreational fisheries. The Chicago Sanitary and Shipping Canal is an important biological conduit between the Mississippi River Basin, where invasive Asian carp are abundant, and the Great Lakes. Millions of dollars have been spent to erect an electric barrier defense in the canal to prevent movement of Asian carp into the Great Lakes, but the need for additional fish deterrent technologies to supplement the existing barrier is warranted. Scientists with the U.S. Geological Survey Northern Rocky Mountain Science Center are examining seismic water gun technology, formerly used in oceanic oil exploration, as a fish deterrent. The goal of the current study is to employ telemetry and sonar monitoring equipment to assess the behavioral response of Asian carp to seismic water guns and the sound energy it generates.

\section{Asian Carp in the United States}

Bighead (Hypophthalmichthys nobilis) and silver carp (H. molitrix), collectively known as Asian carp, were introduced into the United States in the 1970s to enhance water-quality conditions in fish hatcheries. By the early 1980s, Asian carp were found in the Arkansas River and other drainages nearby (Freeze and Henderson, 1982). Populations of Asian carp have rapidly expanded throughout the Mississippi River Basin, establishing reproductive populations in the Mississippi (Williamson and Garvey, 2005), lower Missouri (Shrank and others, 2001), and Illinois Rivers (DeGrandchamp and others, 2008; Irons and others, 2007). There is substantial concern about the potential invasion of Asian carp into the Great Lakes from the Mississippi River Basin. Though there have been no live captures in the lakes, the DNA of carp has been detected indicating that this invader may be on the threshold of the Great Lakes ecosystem.

Asian carp are opportunistic planktivores that feed on zooplankton and phytoplankton. They can grow very large (up to 1.5 meters in length) and reproduce at a high rate (up to 1 million eggs; Kolar and others, 2005). If established in the Great Lakes, Asian carp are likely to have negative ecological, economic and social effects. For example, Asian carp may deplete plankton resources and adversely affect native planktivorous fishes, including paddlefish (Polyodon spathula), bigmouth

${ }^{1}$ U. S. Geological Survey.

${ }^{2}$ Smith-Root, Inc.

${ }^{3}$ Southern Illinois University at Carbondale, Illinois.

${ }^{4}$ University of Illinois at Urbana-Champaign, Illinois. buffalo (Ictiobus cyprinellus) and gizzard shad (Dorosoma cepedianum) (Kolar and others, 2005) thereby directly affecting sport and commercial fisheries industries in the Great Lakes.

\section{Great Lakes Electrical Barrier Defense}

The Chicago Sanitary and Shipping Canal (CSSC), part of the Chicago Area Waterway System, is an artificial canal that moves water from Lake Michigan into the Illinois River, and is a biological connector between the Mississippi River Basin and the Great Lakes. Asian carp currently occupy the Illinois River and have been documented at the entry of the shipping canal. To prevent the spread of Asian carp into Lake Michigan, an electrical barrier system was installed across the Chicago shipping canal in 2002. In 2009, the Army Corps of Engineers funded the development of a more permanent electric barrier and in 2011 a third barrier was installed just upstream.

Electrical barrier systems have been shown to be effective at deterring Asian carp in a laboratory setting (Pegg and Chick, 2002). However, bighead carp DNA recently was detected upstream of the electric barrier, which suggests Asian carp may have moved through the barrier (Jerde and others, 2010) during a period when the barrier was turned off for maintenance. There is no evidence that there are reproductive populations in Lake Michigan at this time, but this canal is a likely avenue of invasion (Cudmore and others, 2012). Additional barrier technologies in the canal may bolster efforts to prevent the invasion of Asian carp into the Great Lakes.

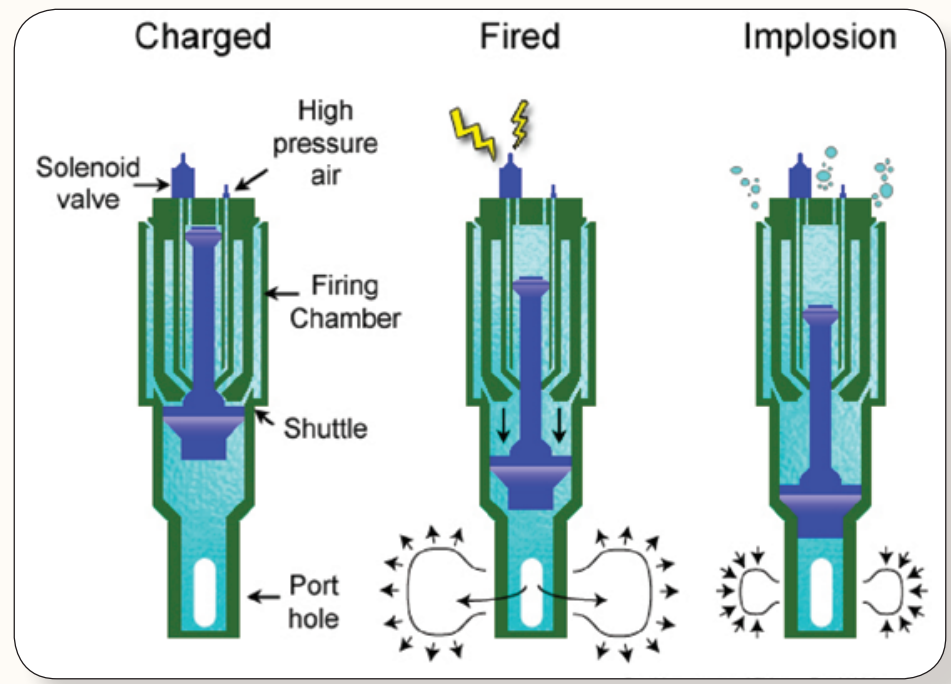

Diagram illustrating the phases that occur during a water gun firing event. Diagram courtesy of M. Ebinger, B. Farokhkish, and T. Wagner, U.S. Geological Survey. 


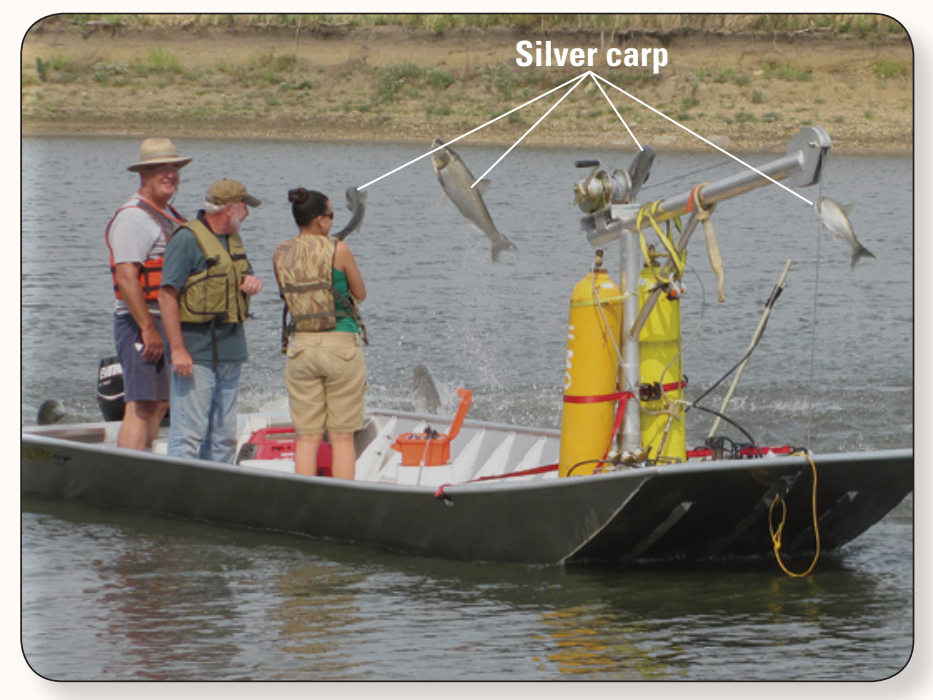

Silver carp (Hypophthalmichthys molitrix) near seismic gun (photograph by Jackson Gross, U.S. Geological Survey).

\section{Alternative Fish Deterrents-Seismic Water Guns}

and researchers tested the lethal effects of this technology on Northern pike, an invasive fish in southern Alaska (Sepulveda and others, 2013). Firing seismic water guns induced ruptured swimbladders and mortality in pike (Gross and others, 2013).

In the fall of 2011, researchers from the USGS Northern

Rocky Mountain Science Center, assisted by the Illinois Water Science Center, deployed a water gun in the CSSC as a barrier defense while the electric barriers were down for maintenance. This apparently successful defense prompted additional studies in the spring of 2012 to determine the mechanisms responsible for carp avoidance.

\section{Study Approach}

Field work was conducted at Material Services Gravel Pit, an artificial backwater channel connected to the Illinois River in May 2012. Researchers tested the response of Asian carp to water gun technology in an experimental fish enclosure, constructed of a purse seine net (180-m long x 10-m wide) that was similar in dimensions to the shipping canal. Two P-400 water guns (400-in ${ }^{3}$; Bolt Technology, Norwalk, Conn., USA) were suspended adjacent to the center of the enclosure from two pontoon floats. Fish were placed in the enclosure 18 hours
Seismic technologies were developed to create underwater sound, and are used in the marine oil exploration industry to assess the geological structure of the ocean floor. These water guns, as they are called within the seismic survey industry, generate high pressure sound energy waves and may function as a fish deterrent (Gross and others, 2013). Researchers are examining Asian carp response to water gun firing to determine if the high pressure sound energy waves can be deployed as an effective barrier to repel Asian carp and as a supplement to the existing electric barrier.

Seismic water guns generate high pressure sound energy waves. These sound waves are produced by the water gun compressing water within a cylinder with a piston. As the ensuing cavity collapses, an implosion occurs, much like a thunderclap, and sound is generated; characterized by a large and rapid positive to negative (peak to peak) pressure pulse.

Fish detect sound through sensory receptors in their inner ear and lateral line and are sensitive to certain frequencies (Bullen and Carlson, 2003). As a result, sound can be used to induce behavioral modification in fish (Popper and Carlson, 1998). In a preliminary water gun deterrent experiment in 2010, USGS researchers implemented a seismic water gun (Bolt Technology, Norwalk, Connecticut, USA) to repel silver carp and cause these fish to change position (Gross, unpub. data 2010). Another study demonstrated how acoustic deterrent technologies that produce sound in the range of 20-2,000 hertz can deter bighead carp (Pegg and Chick, 2002). Seismic water guns can generate sound pulses within that frequency range (Hutchinson and Detrick, 1984; Tree and others, 1986),

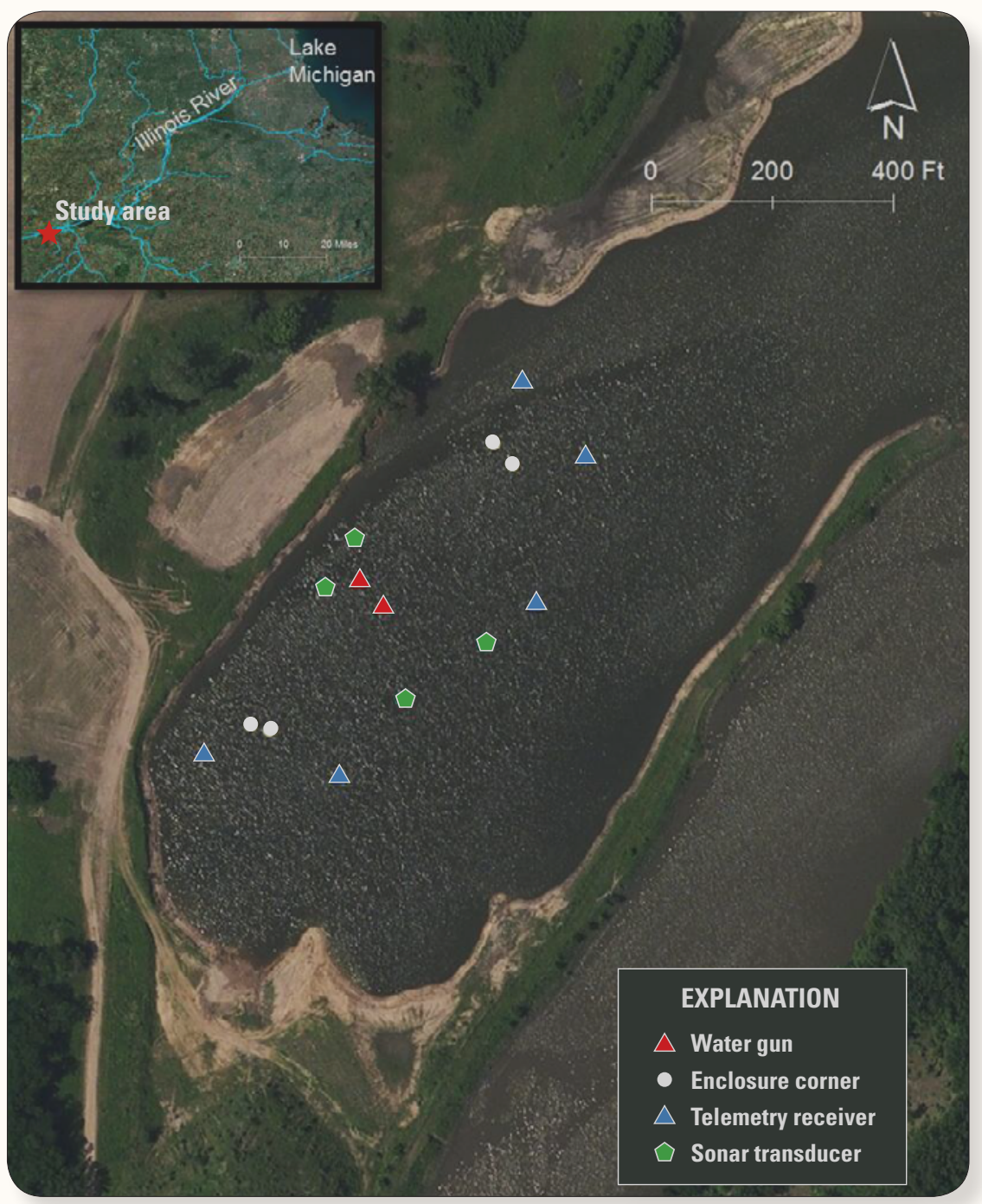

Study area located in Material Services Gravel Pit; backwater habitat of Illinois River near Morris, Illinois. 


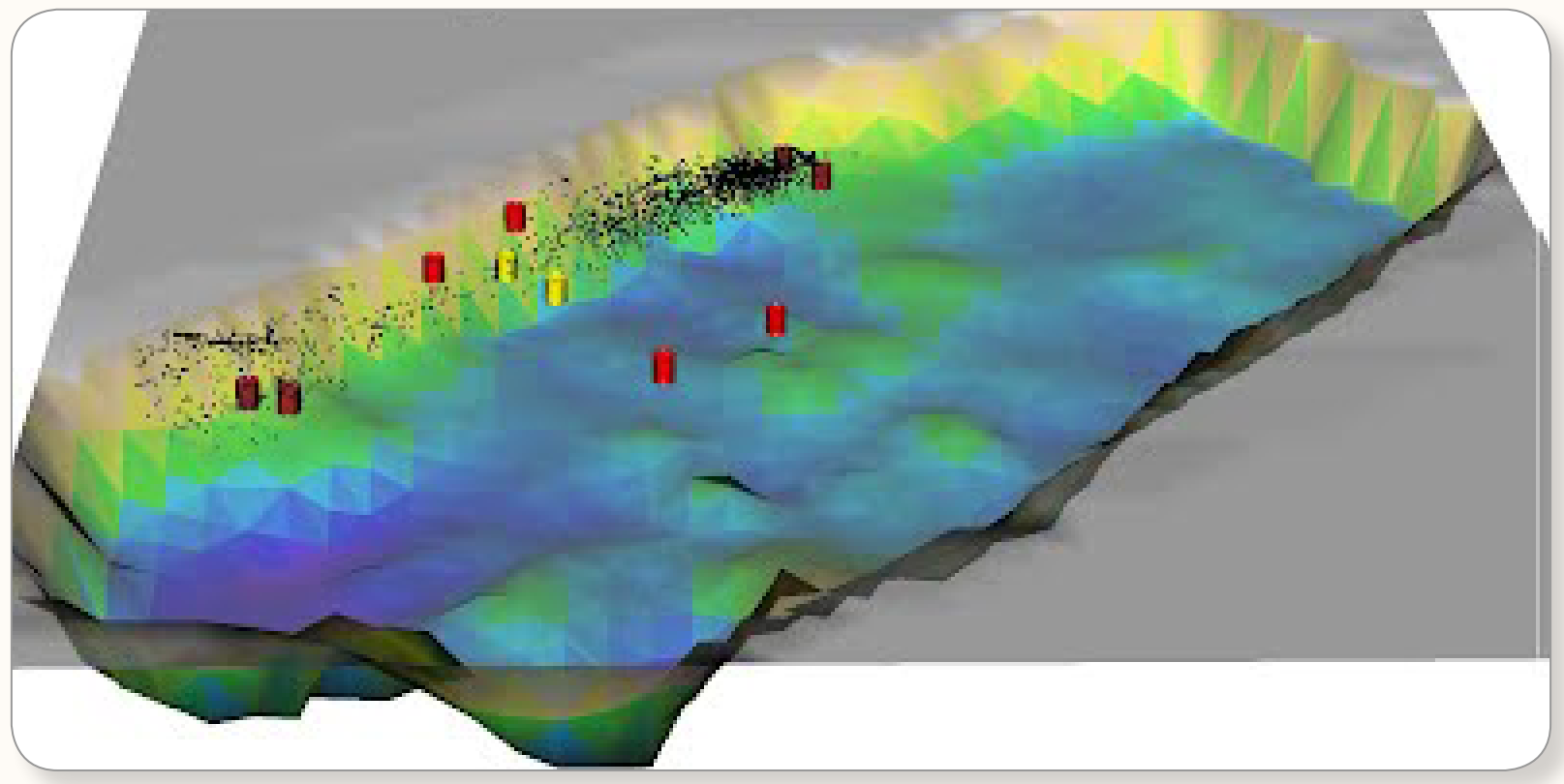

Three-dimensional representation of study site showing bathymetry (courtesy David Glover, Southern Illinois University), locations of the water cannons (yellow cylinders), Biosonics transducers (red cylinders) and relative locations of the net corners (dark red cylinders). Black dots are locations of bighead carp as determined by the telemetry positioning array (image by Jason Romine, U.S. Geological Survey).

before the experiments. Experiments were conducted on 2 days and consisted of one gun firing every 10 seconds, alternating between guns, for a 1-hour period, three times per day.

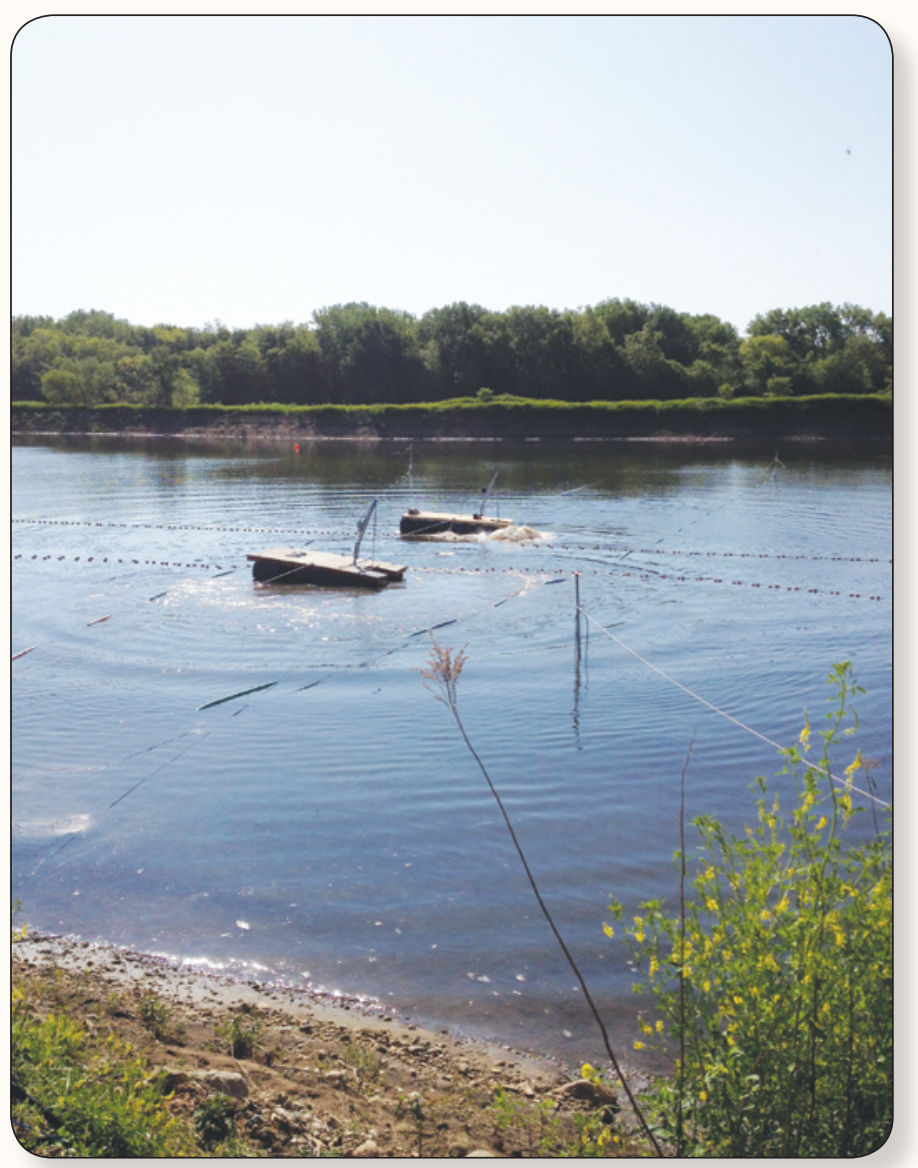

Water gun firing at Material Services Gravel Pit, near Morris, Illinois, May 2012. Water guns suspended from pontoon floats (photograph by Jeffrey Kershner, U.S. Geological Survey).
On the first day, 75 bighead carp [96.0 \pm 6.5 centimeter $(\mathrm{cm})$; mean \pm standard deviation total length] and 76 silver carp $(66.2 \pm 5.3 \mathrm{~cm})$ were placed into the fish enclosure. To test if carp moved away from the water guns, acoustic tags were inserted into all bighead carp to track their movement. On the second day, researchers 56 tagged bighead carp and 23 silver carp from the enclosure. Subsequently, another 56 tagged bighead carp $(97.2 \pm 8.1 \mathrm{~cm}), 31$ untagged bighead carp (97.0 $\pm 5.8 \mathrm{~cm}$ ), and 28 untagged silver carp were placed in the enclosure.

Five LOTEK acoustic hydrophone receivers (LOTEK Wireless, Inc., Newmarket, Ontario, Canada) were positioned around the enclosure to monitor tagged bighead carp movement before, during, and after firing. Two BioSonics 200-kilohertz $(\mathrm{kHz})$ split beam digital transducers (DT-X system, Biosonics Inc., Seattle, Washington, USA) were deployed on each side of the enclosure near the guns. Transducers recorded hydroacoustic data associated with fish detections and movement in range of the transducer beam. Specifically, data were collected on the number of bighead and silver carp detections (presence/absence in transducer beam) and direction of movement before, during, and after firing.

\section{Expected Outcomes of Water Gun Experiment}

Results of this study will provide information on the utility of seismic water guns to repel Asian carp, and thus determine their applicability for use as a barrier defense technology in the Chicago Sanitary and Shipping Canal. Data will also be generated on the relative proximity of Asian carp to the guns before, during, and after firing, as well as demonstrate the use of acoustic telemetry and sonar for future use in monitoring Asian carp behavior near barrier structures or in studies of deterrents.

Disclaimer: Any use of trade, product or firm names is for descriptive purposes only and does not imply endorsement by the U.S. Government. 


\section{References Cited}

Bullen, C.R., and Carlson, T.J., 2003, Non-physical fish barrier systems - Their development and potential applications to marine ranching: Reviews in Fish Biology and Fisheries, v. 13 , no. 2 , p. 201-121.

Cudmore, B., Mandrak, N.E., Dettmers ,J.M., Chapman, D.C., and Kolar, C.S., 2012, Binational Ecological Risk Assessment of bigheaded carps (Hypophthalmichthys spp.) for the Great Lakes Basin. Fisheries and Oceans Canada, Research Document 2011/114. ISSN 1499-3848.

DeGrandchamp, K.L., Garvey, J.E., and Colombo, R.E., 2008, Movement and habitat selection by invasive Asian carps in a large river. Transactions of the American Fisheries Society, v. 137: p. 45-56.

Freeze, M. and Henderson, S., 1982, Distribution and status of the bighead carp and silver carp in Arkansas: North American Journal of Fisheries Management, v. 2, no. 2, p. 197-200.

Gross, J.A., Irvine K.M., Wilmoth, S., Wagner, T.L., Shields, P.A., and Fox, J.R., 2013, Effects of pulse pressure from seismic water gun technology on Northern pike. Transactions of the American Fisheries Society 142(5): p. 1335-1346.

Hutchinson, D.R., and Detrick, R.S., 1984, Water gun vs. air gun: a comparison. Marine Geophysical Researchers, v. 6: p. 295-310.

Irons, K.S., Sass, G.G., McClelland, M.A., and Stafford, J.D., 2007, Reduced condition factor of two native fish species coincident with invasion of non-native Asian carps in the Illinois River, U.S.A. Is this evidence for competition and reduced fitness? Journal of Fish Biology, v. 71: p. 258-273.

For more information concerning this publication, contact:

Director, USGS Northern Rocky Mountain Science Center

2327 University Way, Suite 2

Bozeman, MT 59715

(406) 994-7544

Or visit the Northern Rocky Mountain Science Center Web site at:

http://www.nrmsc.usgs.gov
Jerde, C.L., Mahon, A.R., Chadderton, W.L., and Lodge, D.M., 2011, "Sight-unseen" detection of rare aquatic species using environmental DNA. Conservation Letters, v. 4, no. 2, p. $150-157$.

Kolar, C. S., Chapman, D.C., Courtenay Jr., W.R., Housel, C.M., Williams, J.D., and Jennings, D.P., 2005, Asian Carps of the Genus Hypophthalmichthys (Pisces, Cyprinidae)-A Biological Synopsis and Environmental Risk Assessment. Report U.S. Fish \& Wildlife Service Report, Interagency Agreement 94400-3-0128.

Pegg, M.A., and Chick, J.H., 2002, Aquatic Nuisance Species: An evaluation of barriers for preventing the spread of bighead and silver carp to the Great Lakes. Final Report, IllinoisIndiana Sea Grant (A/SE (ANS)-01-01), accessed on November 12, 2012 at http://www.iisgcp.org/research/ais/pegg.html.

Popper, A.N., and Carlson, T.J., 1998, Application of sound and other stimuli to control fish behavior. Transactions of the American Fisheries Society v.127, no. 5, p. 673-707.

Schrank, S.J., Braaten, P.J., and Guy, C.S., 2001, Spatiotemporal variation in density of larval bighead carp in the lower Missouri River. Transactions of the American Fisheries Society, v. 130 , no. 5 , p. $809-814$.

Sepulveda, A.J., Rutz, D.S., Ivey, S.S., Dunker, K.J., and Gross, J.A., 2013, Introduced Northern pike predation on salmonids in Southcentral Alaska. Ecology of Freshwater Fish, v. 22, p. 268-279.

Tree, E.L., Lugg, R.D., and Brummitt, J.G., 1986, Why waterguns? Geophysical Prospecting, v. 34, p. 302-329.

Williamson, C.J., and Garvey, J.E., 2005, Growth, fecundity, and diets of newly established silver carp in the middle Mississippi River. Transactions of the American Fisheries Society, v. 134, p. 1423-1430. 